\title{
Online Journal Aggregator System Design Using User Centered Design (UCD) Approach
}

\author{
Irawan Afrianto ${ }^{\mathrm{a} 1}$, Sufa atin ${ }^{\mathrm{a} 2}$, Andri Heryandi ${ }^{\mathrm{a} 3}$, Lia Warlina ${ }^{\mathrm{b} 4}$ \\ ${ }^{a}$ Informatics Engineering, Universitas Komputer Indonesia \\ Jl. Dipati Ukur No.112-116 Bandung, Indonesia \\ 1irawan.afrianto@email.unikom.ac.id (Corresponding author), ${ }^{2}$ sufaatin@email.unikom.ac.id , \\ ${ }^{3}$ andri.heryandi@email.unikom.ac.id \\ ${ }^{\mathrm{b}}$ Departement of Urban and Regional Planning, Indonesian Computer University \\ Jl. Dipati Ukur No.112-116 Bandung, Indonesia \\ ${ }^{4}$ lia.warlina@email.unikom.ac.id
}

\begin{abstract}
Journal as a medium to explain the results of research. It has developed in such a way especially because of the rapid support of information and communication technology today. Various models of online-based journaling management can be easily operated by journals managers as well as writers / researchers who will include research results in the journal. It's just that with the number of journals that exist today, causing difficulties for the manager of journals to be able to promote the journals he managed, in addition to the manager of the journal sometimes difficult to get a researcher who would put his paper into the journal he manages. Meanwhile, with the number of journals that have been online, researchers will find it difficult to get information from the journals. Researchers should open their journal entries, read their profiles and publications, until they are interested to include papers in the journal. This problem is the background of the development of online journals aggregator system, which with this system will facilitate the meeting between journals, journal managers and writers or researchers. In order to develop an online journal aggregator system, a software development method is needed that directly captures the needs of its users. This study aims to implement the UCD method in the functional design and interface of the aggregator journal system. In order to determine the level of acceptance and support of prospective users of the aggregator journal system. Measurements were taken using Likert method with user acceptance preferences for 3 aspects of the system, namely: accessibility, navigation, and content aspects. The measurement results show $82 \%$ of prospective users state that the functional design and interface of the aggregator journal system can be accepted and can be developed to the next stage.
\end{abstract}

Keywords: Journal, Aggregator, Online, User-Centered Design (UCD), Design

\section{Introduction}

Journals are an important information medium for science and technology. A journal is a collection of articles or papers that are published periodically, written by the researchers to present the results of research that has been done and reviewed by the best-trusted partner. Therefore, the continuity of scientific journals becomes a very important thing for the development of science and technology in order to know the scientific development up to the latest.

The development of information and communication technology (ICT) providing assistance to the journal management with the online-based journal management system. On the one hand it helps journalists in disseminating information and manage their journals, on the other hand for research with the online version of the journal makes it easy to perform a transaction related articles to be included in the journal. With the increasing number of online journals, there are a problem that is often complained by the journal managers, researchers, and public. For the 
journal managers, an increasing number of online journal in the field of science, an effective promotion is needed to introduce the journal to the researchers. Meanwhile, the researchers find it difficult and take a long time to find and open one by one journal web pages to view the profile of the journal which is supposed to accept the results of the research he wrote. While the public needs an access to obtain an information related to the results of research in more detail and complete in the same places.

Aggregator system can be used as a solution, this is because aggregation has emerged as a valuable service to help internet users worldwide. It provides value added e-services, by collecting relevant data on the web and turns them into useful information [1]. Research on ecommerce aggregator system has been done by Raka Yusuf which allows users to search for various products without having to open one by one existing e-commerce site [2]. Other aggregator system research is done by Nydia et al, that is news aggregators who can give an automatic recommendation of any news according to their needs [3]. The aggregator can be various forms in the electronic or digital era. There are three aggregator classifications. The first type is that focusing on providing host (content host). The second type is indexing or categorizing content differently from other content (the gateway). The third type is the traditional aggregators licensed on full text content (full text aggregator) [4]. The most widely used aggregator is a news aggregator. Some research indicates the existence of news aggregator is detrimental to the original news site. Survey results show that newspapers or news websites are in a state of concern. Newspapers become depend on Facebook and Google (on search and news). News aggregator lowers traffic from newspaper sites but increases news article traffic. In the end, the user will ignore the original source [5]. The closure of google news reduces news consumption by $20 \%$ and decreases the view of other publishers by $10 \%$. This also lowers the view on breaking news, hard news and unfavorable news [6]. However, news aggregators such as the Financial Times and The Wall Street Journal have successfully charged consumers [7]. Europeana is a library aggregator in Europe that is an organization that collects metadata from a group of content providers and distributes it. This aggregator collects material from individual organizations then standardizes file and metadata format and distributes metadata to Europeana according to SOP. This aggregator also supports content providers in terms of administration, operations, and training [8]. The same aggregator in Europe for the field of culture is the Italian Culture. Culture Italia is a national aggregator that manages culture in Italy. This cultural manager covers all sectors at the local, regional and national levels. The aggregator portal manages 2.4 million metadata from 32 private and public partners including thematic aggregators such as Italian-owned Internet Culturale library [9]. Some libraries in Indonesia have used an aggregator to facilitate librarians in universities. Aggregator as a tool to add information in library collections from various websites. Other roles of aggregators for library collections include: (a) to facilitate the user in accessing the collection without open some websites; (b) to form a positive image for the library: and (c) data entry processing to help librarians in updating references or collections [10].

UCD is used as a method in system design, due to its ease in interaction mechanisms with users who are involved in the field by utilizing user opinions, patterns of user behavior [11]. The essence of UCD's approach is that it provides a structure to assist developers in ensuring that relevant designs have been considered in a user-oriented manner [12]. Research on UCD related to system development has been done by Edwar Ali, where UCD method can trigger the creativity of the parties involved in preparing the desired software specification [13]. Based on Astri et al research, UCD can be implemented to design game-based learning applications that can improve children's learning motivation [14].

It underlies this research, which is utilizing the UCD method in developing the aggregator system of online journal. The online journals aggregator system takes the concept of a web portal that will be a meeting system between journal managers, journal, researchers, and visitor. It's will facilitate the journal managers to be able to promote the journals he managed, inviting potential researchers to include their research article and journal transactions inside it. For the researcher, online journals aggregator system will be a means to choose, like and keep journals that are considered according to the scientific field, so it will facilitate researchers to obtain information related to the journal. As for the general public, the online journals aggregator system will provide search facilities in journals, articles and authors in the same system[15]. 
So the purpose of journal aggregator design using UCD are (1) to build an interface system between researcher / author of a paper with journals managed by the manager of the journal, which can: (a) Facilitate the researchers / writers in searching and viewing journals in accordance with their scientific fields, discussion and journal transactions ; (b) Facilitate journal manager in promoting their journals and getting potential researchers / authors; (2) to produce an integrated system of management the journals for researchers / authors and journal manager.

\section{Research Methods}

\subsection{Data Collection Method}

The method of data collection and design of information systems are as follows, shows in figure 1 :

- Interview : interviews are conducted to interact directly or indirectly with parties involved in the journal community, that is journal managers, authors / researchers, and community members who need access to the journal.

- Observation : this observation is done by observing directly on the research object and the developing unit. Because researchers are in a position that is also as a user, then this activity is relatively easier to do. In addition, online systems in the field of the journal into a medium to make comparisons with systems to be developed.

- Literature review : reviewing the literature used, either in the form of library books, research results, and other sources.

\subsection{System Design Method Using UCD}

The method used in the software design is the User-Centered Design (UCD) method. This method is a method that sets the user as the center of system development. The process of User-Centered Design (UCD) Method which includes 5 processes as follow:

a. Plan the human-centered process : Conduct interview stages and discussions with prospective users on system design in both functional, non-functional and system interfaces.

b. Specify the context of use : This stage, the researcher provides a description of the business functions carried out by the user in accordance with user needs, and describes the data and information contained in the system design..

c. Specify user and organizational requirements : Researchers describe the functional of a system developed using UML and define non-functional requirements so that the system can run well during implementation

d. Product design solutions: The researcher designed the aggregator system interface according to the needs and functions of each user

e. Evaluate design against user requirements : Evaluate the system design developed to potential users related to the usability of the system whether it meets expectations or not. 


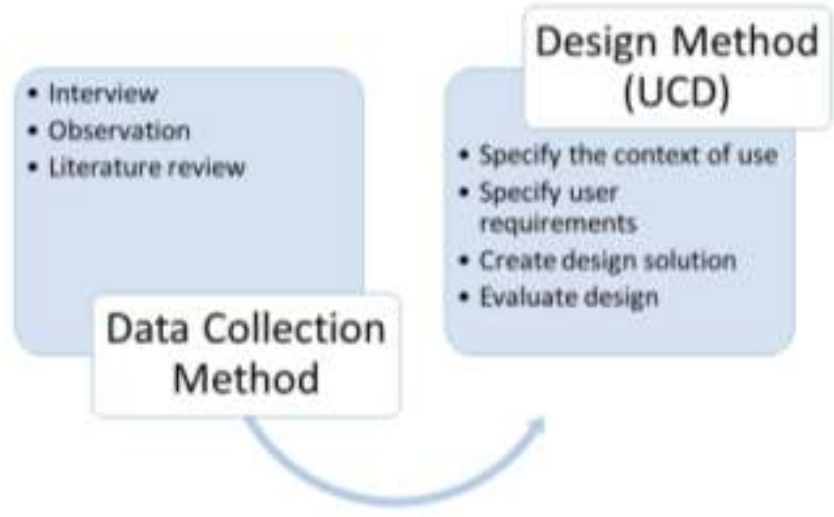

Figure 1. Research Method (revisi)

\section{Result and Discussion}

\subsection{Data Analysis}

This research conducted interviews and discussions with the journal manager and the authors. the respondents involved in this research amounted to 30 people, namely 10 journal managers and 20 researchers. Table 1 shows the result of data analysis.

Table 1. Result of Data Analysis

\begin{tabular}{|c|c|c|c|}
\hline \multirow{2}{*}{$\begin{array}{c}\text { No } \\
1\end{array}$} & Data Collection & Object & Result \\
\hline & Interview, discussion & Writer/ researcher & $\begin{array}{l}\text { - } \text { Difficulty finding writers / } \\
\text { researchers } \\
\text { - Difficulty finding papers for } \\
\text { publication } \\
\text { - } \quad \text { The absence of media to } \\
\text { promote his journal } \\
\text { - } \quad \text { Access to many online journals } \\
\text { - Different journal profiles }\end{array}$ \\
\hline 2 & Identification & Journal sample & $\begin{array}{ll}\text { - Journal format } \\
\text { - Journal identity } \\
\end{array}$ \\
\hline 3 & Observation & $\begin{array}{l}\text { Journal management } \\
\text { systems (online) }\end{array}$ & $\begin{array}{l}\text { - Functions that exist on the } \\
\text { system } \\
\text { - Users } \\
\text { - How to use the system }\end{array}$ \\
\hline
\end{tabular}

Similar systems in Indonesia which are the reference for the development of a journal aggregator system are Indonesia One Search (http://onesearch.id/) in Figure 2 and Indonesian Scientific Journal Database (ISJD) (http://isjd.pdii.lipi.go.id/) in Figure 3. Indonesia One Search (IOS) is created by National Library (Perpunas) Republic of Indonesia. Through IOS, users can search public collections of libraries, museums, archives, and e-resources in Indonesia. IOS can be used to input a digital collection repository. 


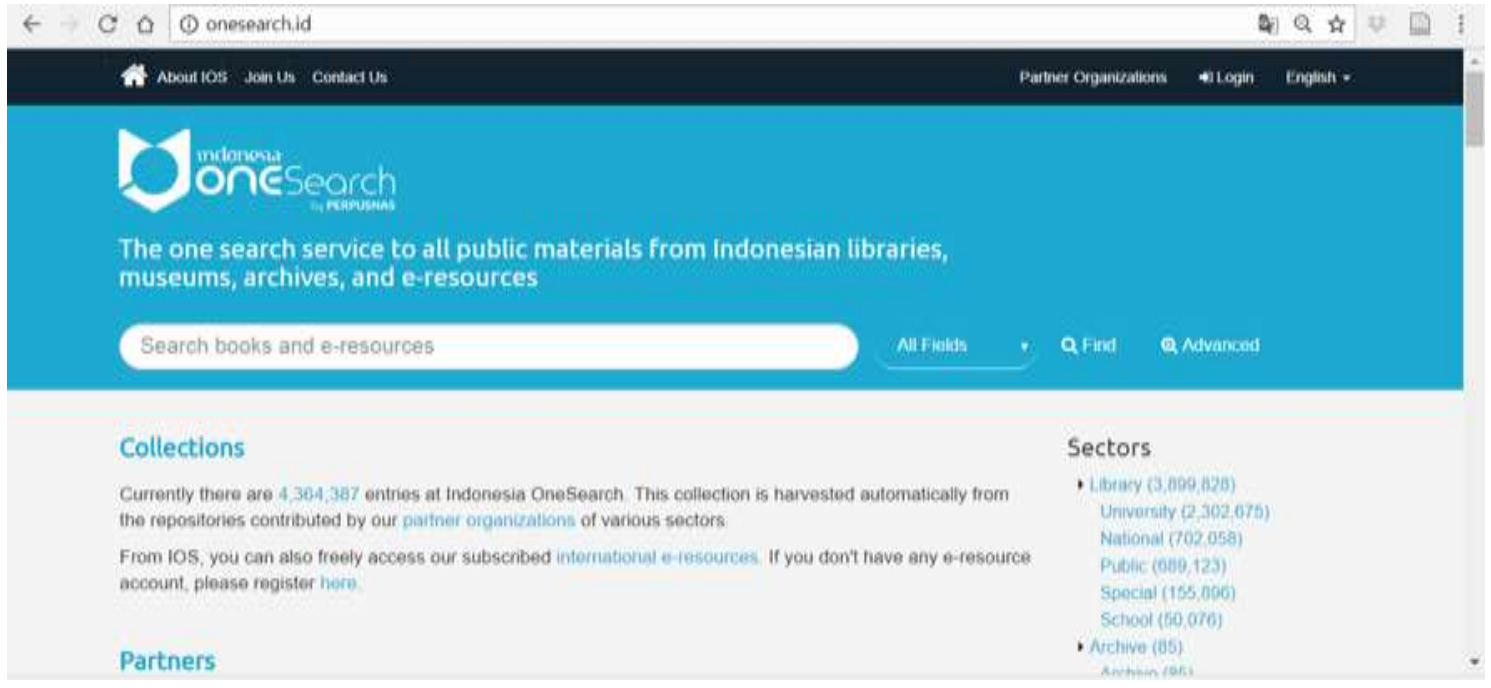

Figure 2. Indonesia One Search

ISJD is one of the sources in the development of journal aggregators because it is the ISSN record center for journals. ISJD is developed by the Indonesian Institute of Sciences (LIPI). Through ISJD registered user may save and download articles

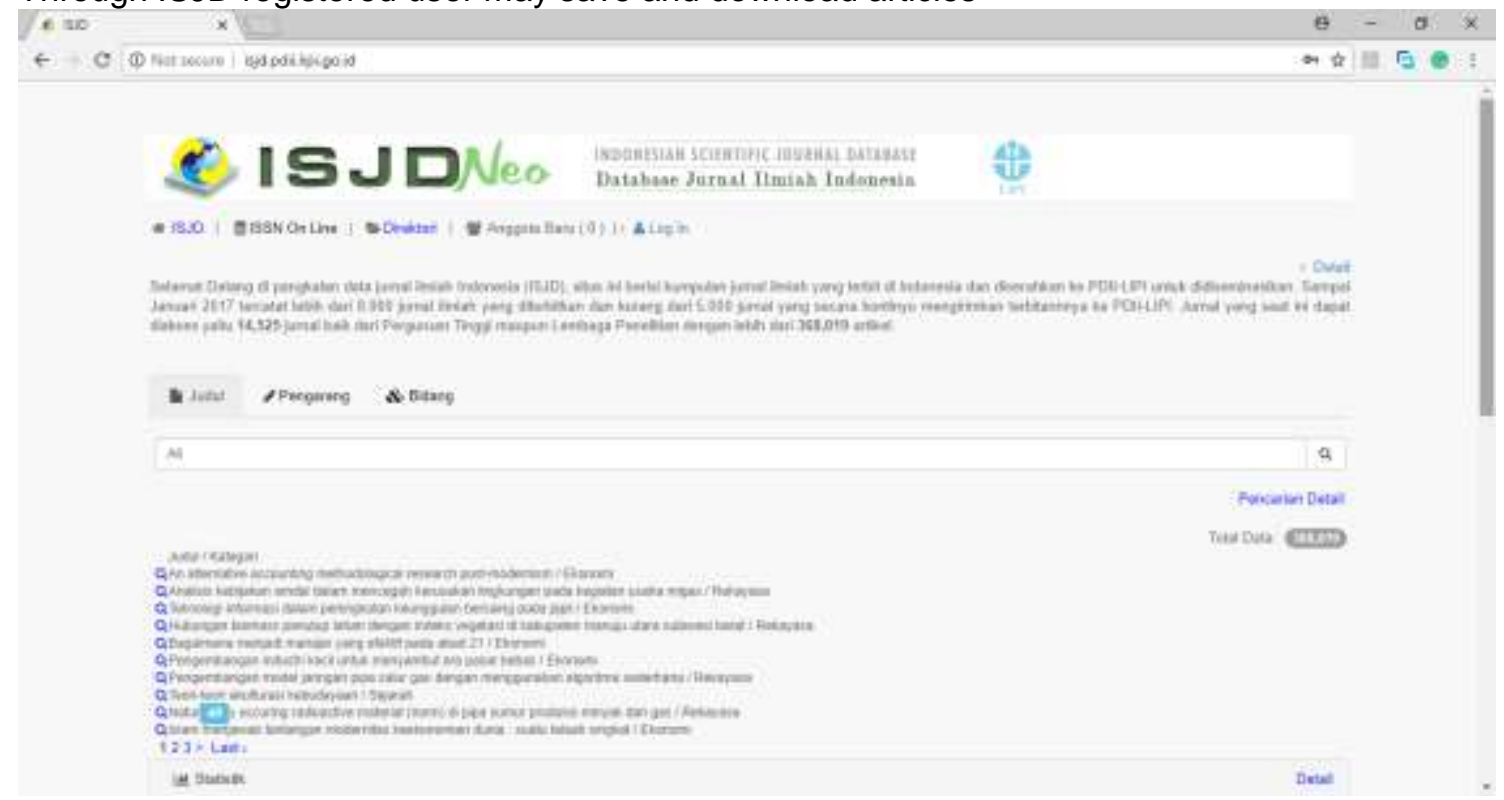

Figure 3. Indonesia Scientific Journal Database (ISJD)

The difference of a journal aggregator with Indonesia One Search (IOS) and Indonesia Scientific Journal Database (ISJD) are within the coverage of work. The journal aggregator can search, mark as favorites and interact with the journal manager. The advantage of journal aggregator is the existence of transactions between researchers / authors with the journal manager in sending the abstract to be assessed and published in the journal.

\subsection{UCD Analysis for Journal Aggregator System}

System development method used in this research is by performing step by step on User Centered Design (UCD) method. This method focuses on the user's aspect, so there is often a misperception in pairing it with other software development methods, such as prototype, waterfall and so on. This method can stand-alone or be used in conjunction with another method. 


\subsubsection{Plan The Human Centered Process Component}

At this stage, the researcher conducts interviews and discussions with prospective users, to find out what users want, namely journal researchers and managers, so that they can instill a commitment that designing an online journal aggregator system using User Centered Design (UCD) can fulfill the desires of users.

\subsubsection{Specify The Context Of Use}

Entering this stage, the researcher will identify the users who will use the system and explain for what and what conditions they will use this product through the technique of identifying stakeholders. This journal aggregator system is designed to provide information that is primarily concerned with the needs of journal managers, researchers, and the general public/visitor. The information presented on this web portal system contains data:
a. Journal profile data
b. Journal manager data
c. Researcher profile data
d. Journal transaction data
e. Abstract and paper data
f. Journal category data
g. News data

The user target of the online journals aggregator system consists of 3 users, shows in table 2 .

Table 2. Target User Of Aggregator Journal Online System

Function
Users who can input data journal, can find
and inform Potential Authors, can favor the
author's abstract, inviting partner, do journal
transactions with author

\subsubsection{Specify User And Organizational Requirements}

Entering this stage the researcher identifies the list detailed of user's need. Based on a survey of potential users of the system there is an information that is required related to the activities of the system design shown in figure 4 , such as :

Functional needs:

a. The system can process the data of the researcher / author

b. The system can process journal manager data

c. The system can process the profiles data of researchers / authors 
d. The system can process journal data

e. The system can process journal category data

f. The system can perform a search of the journal

g. The system can search the researcher / author

h. The system can upload abstract papers

i. The system can favor the journal

j. The system can be distributed journal invitations

k. The system can favor an abstract paper

I. The system can provide confirmation paper

m. The system can spread news related to the journal

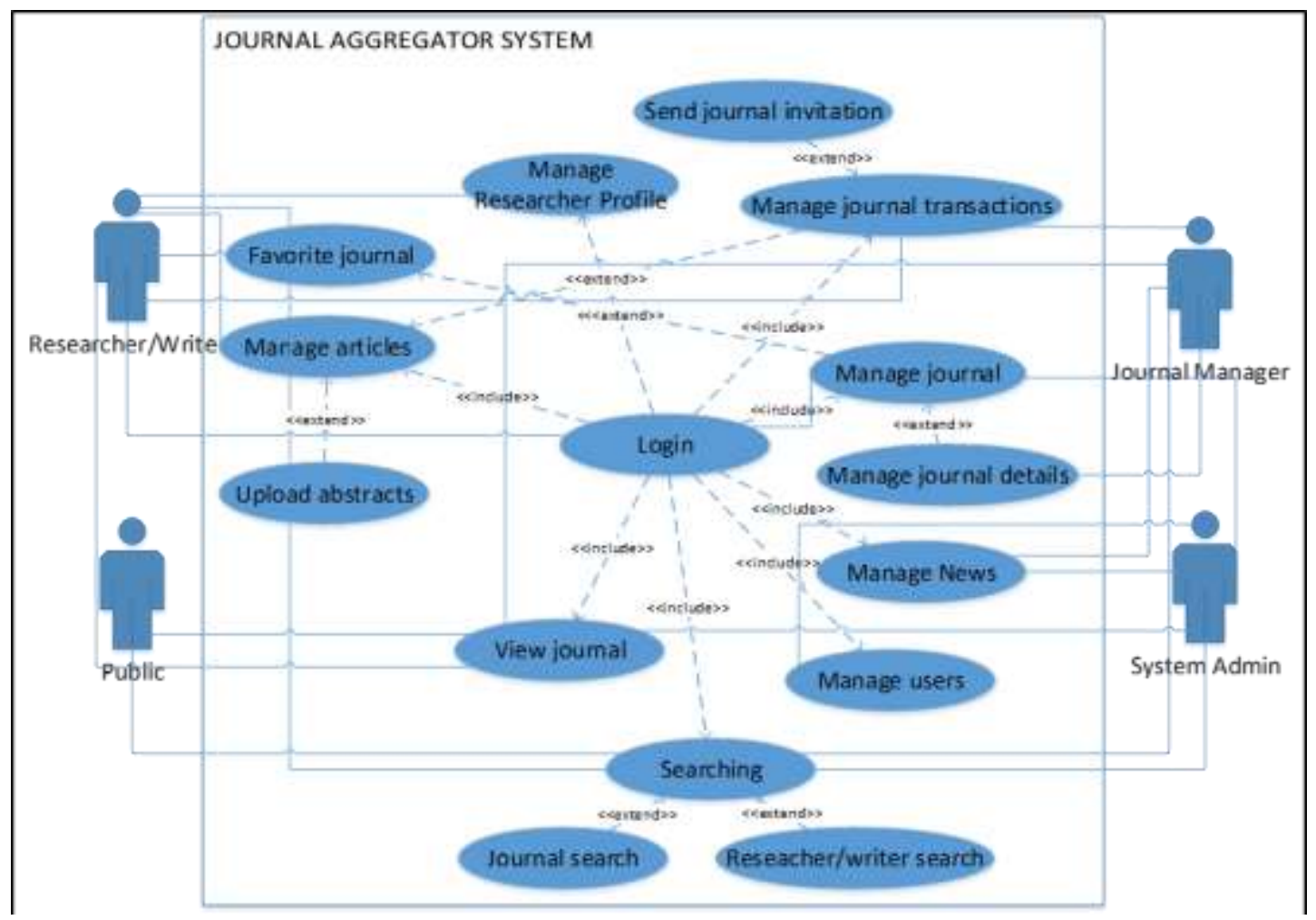

Figure 4. Functional Needs (Use Case Diagram) of Journal Aggregator System

Non-functional needs:

a. The system was built using MySQL database with PHP programming language, CSS and web framework

b. The system works well as long as it's connected to the internet with standard bandwidth

c. There are no specific users to use this system.

d. This system requires an operating system (Windows, Linux) and a web browser to access the system

e. It has a user-friendly interface that is easy to understanding user

f. The system should be able to protect data from unauthorized access.

The architecture of the online journals aggregator system in Figure 5 shows the interaction of users in the system. The author will be facilitated in the search for journals in accordance with the field, save it as a favorite journal and can make transactions with the journals.Journal managers can view abstract submissions or papers from authors, and can actively recommend them for publication in the journals it manages. While visitors are given access to search, read and download papers available in the online journal aggregator system. The system has the 
ability to recommend journals that match the author profile. the system will inform the journal managers, which authors have the potential to send a paper to their journal and can invite them to the journal that their manages. The system also facilitates abstract to papers transactions between authors and journal managers.

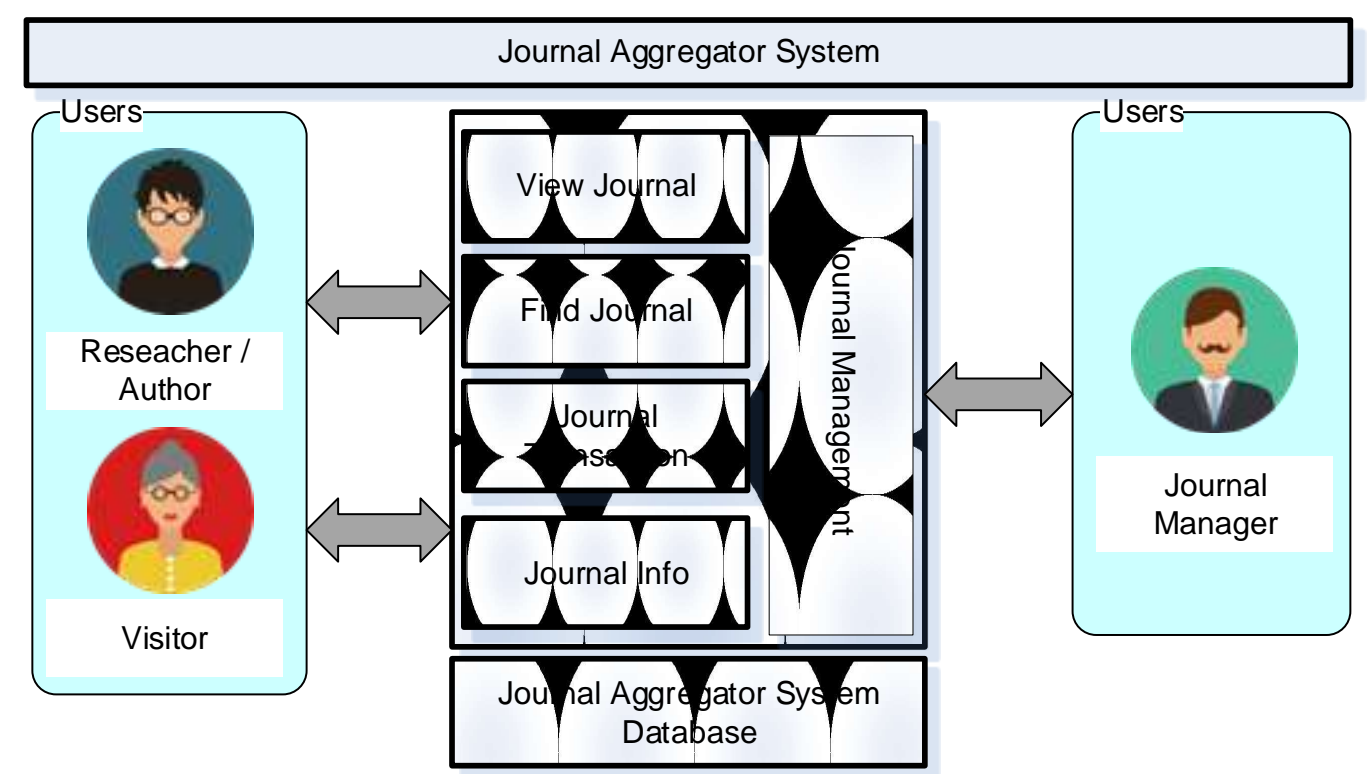

Figure 5. The architecture of the Journal Aggregator System

\subsubsection{Product Design Solutions}

It is the stage of design solutions, where researchers build the design form as a solution of the system to be developed. The prototype system is started from the global to the detailed form will be elaborated on this aspect.

Main display which include : Login interface (figure 6) is used to log into the system, Main Interface (figure 7) contained manage journal interface, manage journal details, spread the journal invitation interface, manage news interface, manage user interface, search the Author/ researcher interface, journal search interface, journal view interface, upload abstract interface, manage papers interface, manage researcher profile interface, favorite journal interface and search interface.

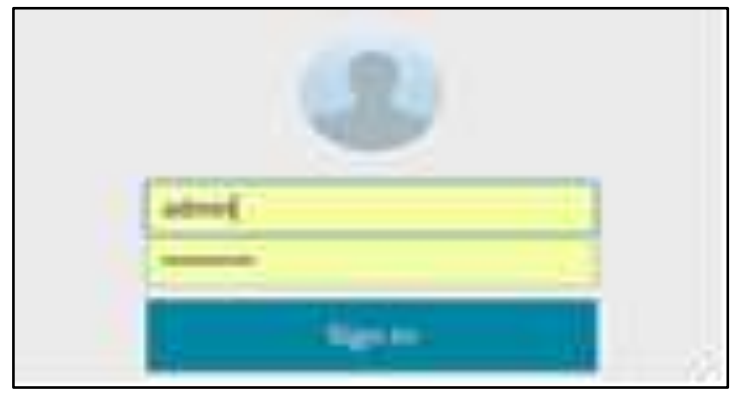

Figure 6. Login Form 


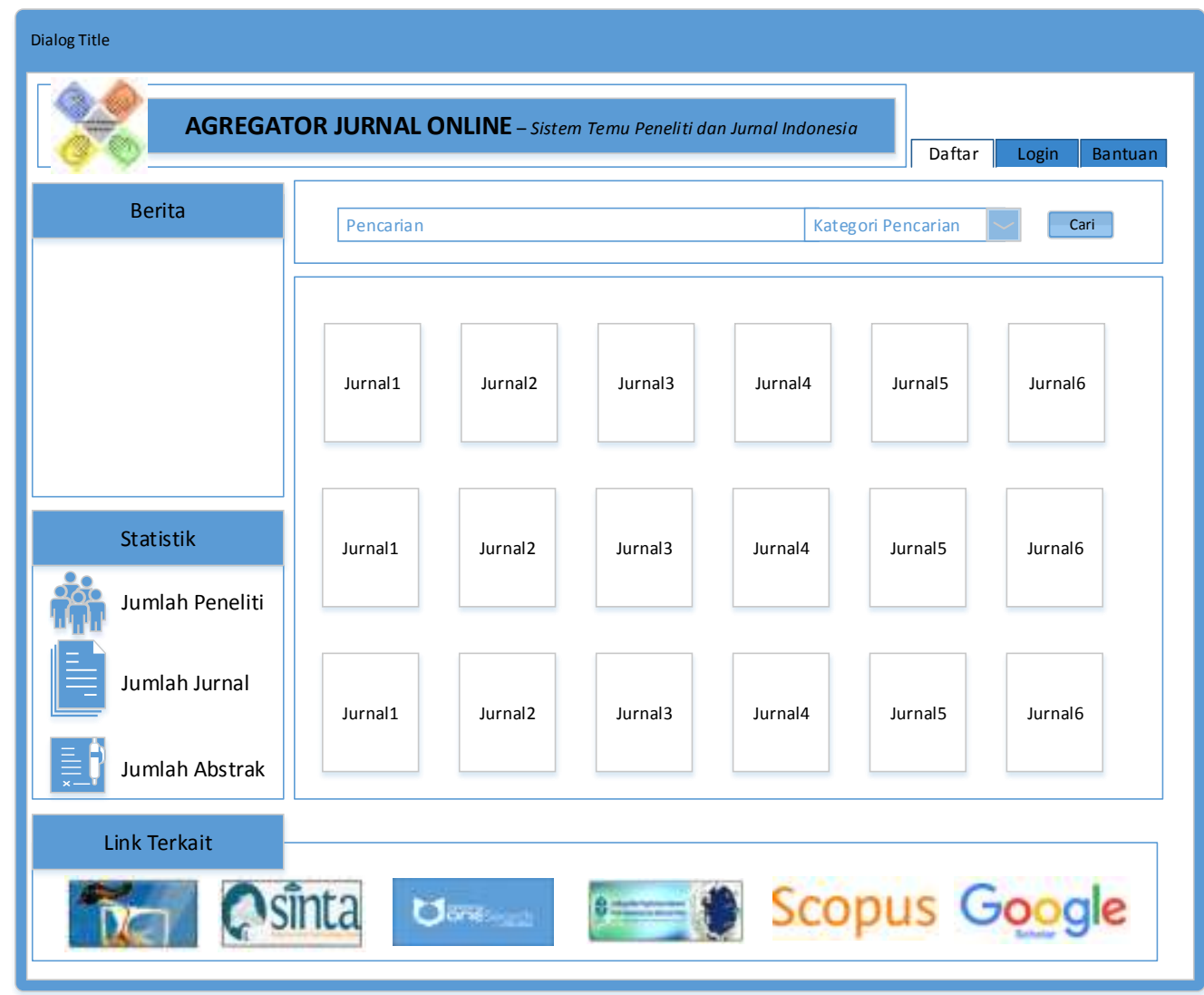

Figure 7. Main Interface Of Journal Aggregator System

Additional displays that include information about links coming from various external sources of the organization. System developers recommend a number of links that will be linked to the online journals aggregator system. the selected links are the results of the questionnaires distributed to 30 potential users. users choose Arjuna, Sinta, OneSearchID, PDII-LIPI, Scopus and Google Sholar as links that can be integrated into the online journal aggregator system (figure 8).

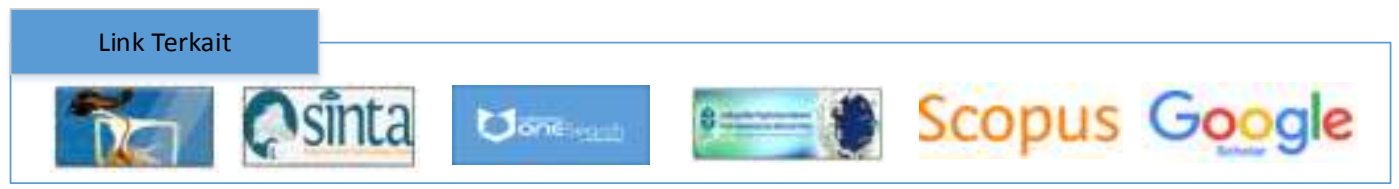

Figure 8. External Links Of Journal Aggregator System

\subsubsection{Evaluate Design Against User Requirements}

The evaluation is done to determine the level of acceptance and support from potential users of the system being developed. Measurements were made using a Linkert scale to 30 prospective system users with the proposed statement covering usability in the system built, namely accessibility aspects, navigation aspects, and content aspects. Evaluation is done by giving ten statements with five response choices for each statement in the form of a Likert scale 1 to 5 , where point 1 means Strongly Disagree (SD) to point 5 which means Strongly Agree (SA) shows at table 3. 
Table 3. Statement of UCD questionnaire

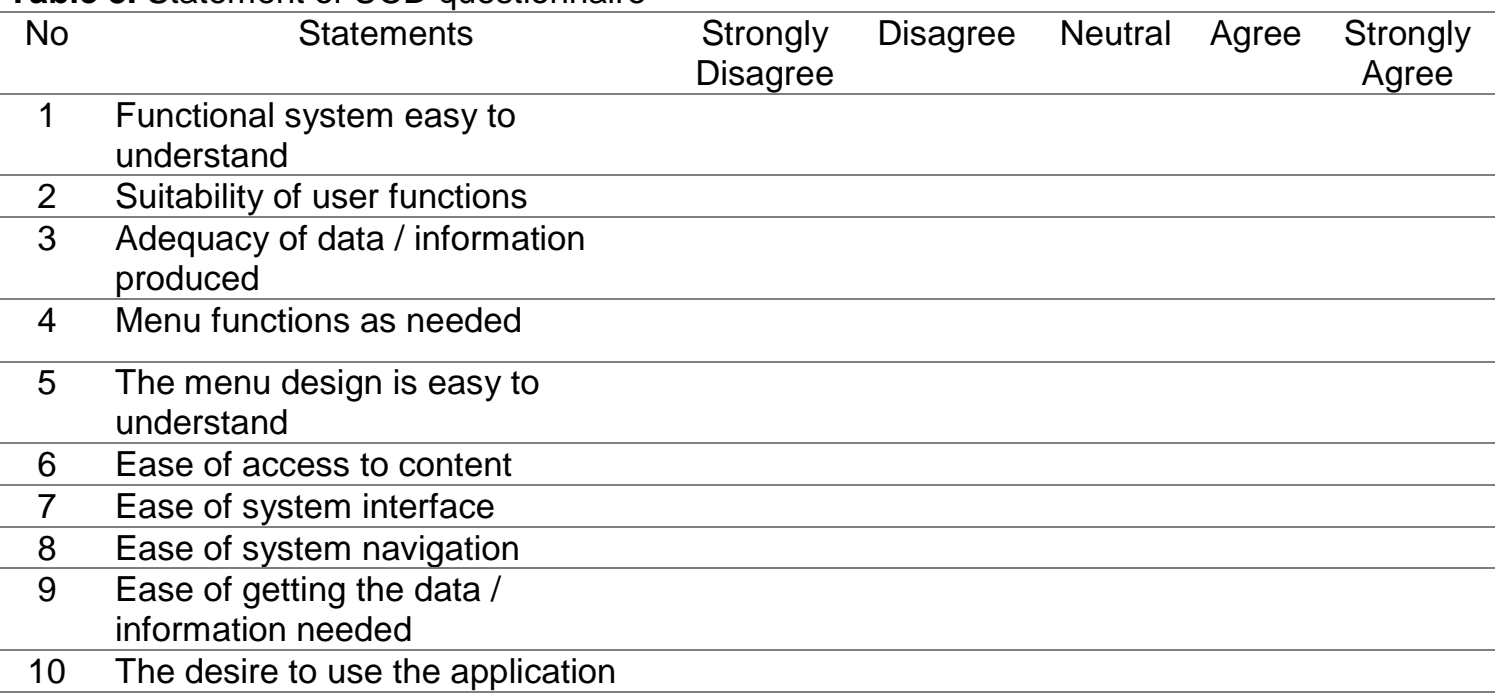

Measurements are made using the rating of user satisfaction preferences for 3 aspects of the application, namely: accessibility, navigation, and content aspects. The total score if the user is satisfied should (all items get a score of 5) is 5 (score) $\times 10$ (number of statements) $\times 30$ (number of participants) $=1500$. The total score from the overall data collection $=1234$. Thus the result of the preference matrix is $1234: 1500=82.2 \%$. If the range is between $300-1500$, the evaluation result is at GOOD intervals.

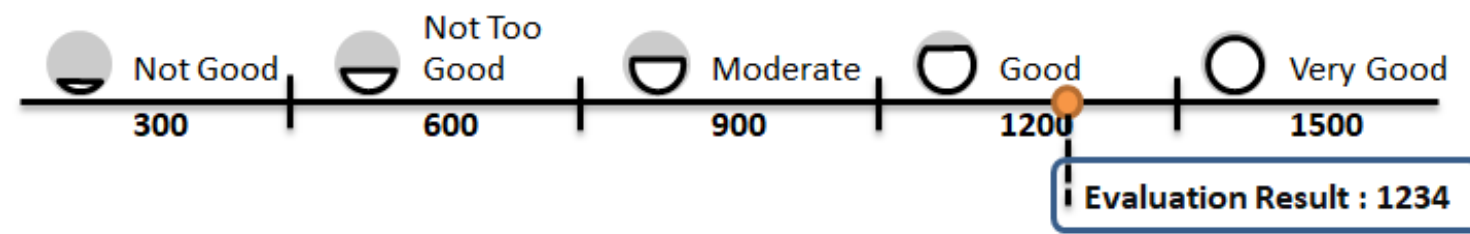

Figure 9. The range of User Satisfaction Preferences

\section{Conclusion}

The results of this study indicate that UCD can be used to produce functional designs and interfaces from online journal aggregator systems. From each stage of the user-centered design method that is carried out, it can be produced a product design that meets the user's user requirements according to the results of interviews and questionnaires. The functionality and interface of the online journal aggregator system have met the usability aspects (accessibility, navigation, and content). This is concluded from the results of functional and interface design evaluations through questionnaires using a Linkert scale which shows that the design built is at a GOOD interval, which means that the functional design and interface of the journal aggregator system can be accepted and can proceed to the next stage. For next research, in order to improve the accuracy of the development of the online journal agegator system, it is necessary to make a propototype based on the results of UCD modeling and design, but it is more intense in interacting with prospective users.

\section{Acknowledgment}

This research project is supported by Directorate of Research and Community Service, Ministry of Research, Technology and Higher Education of Indonesia using grant Penelitian Strategis Nasional Institusi Scheme in 2018 Fiscal Year. 
References

[1] S. Mishra, "Web Aggregation In India: E-Business Models In New Economy," International Journal Of Business And Emerging Markets, Vol. 2, No. 3, Pp. 252-266, 2010.

[2] R. Yusuf, "Aggregator Otomatis Pencari Produk Dengan Pemberitahuan Melalui Surel Menggunakan Fungsi Curl," Jurnal Teknik Informatika, Vol. 8, No. 1, 2015.

[3] N. V. Wahono, A. Wibowo, And R. Intan, "Aplikasi Indonesian News Aggregator Berbasis Android Yang Didukung Oleh Sistem Perekomendasi," Jurnal Infra, Vol. 3, No. 1, Pp. Pp. 121-Pp. 127, 2015.

[4] J. Cummings, "Open Access Journal Content Found In Commercial Full - Text Aggregation Databases And Journal Citation Reports," New Library World, Vol. 114, No. 3/4, Pp. 166-178, Mar. 2013.

[5] D.S. Jeon And N. Nasr, "News Aggregators And Competition Among Newspapers On The Internet," American Economic Journal: Microeconomics, Vol. 8, No. 4, Pp. 91-114, 2016.

[6] S. Athey, M. M. Mobius, And J. Pál, "The Impact Of Aggregators On Internet News Consumption," Stanford Graduate School of Business - Research Paper No. 17-8, 2017.

[7] L. Chiou, C. Tucker, "Content Aggregation By Platforms: The Case Of The News Media”, Journal of Economics \& Management Strategy. Dec;26(4):782-805. 2017.

[8] S. Chambers And W. Schallier, "Bringing Research Libraries Into Europeana: Establishing A Library-Domain Aggregator," LIBER Quarterly, Vol. 20, No. 1, Pp. 105118, 2010.

[9] S. Di Giorgio, "Culturaitalia, The Italian National Content Aggregator In Europeana," Procedia Computer Science,Vol. 38, Pp. 40-43, 2014.

[10] D. F. Saputra, "Agregator Sebagai Alat Pengembangan Koleksi Perpustakaan Berbasis Website," Pustakaloka, Vol. 8, No. 2, Pp. 201-210, 2016.

[11] Y. Saputri, M. Fadhli, And I. Surya, "Penerapan Metode Ucd (User Centered Design) Pada E-Commerce Putri Intan Shop Berbasis Web," Jurnal Teknologi dan Sistem Informasi, Vol. 3, No. 2, Pp. 269-278, 2017.

[12] A. Kusnanjaya, "Perancangan Sistem Informasi Data Guru Menggunakan Pendekatan User Centered Design," Paradigma-Jurnal Komputer dan Informatika, Vol. 16, No. 1, Pp. 1-8, 2014.

[13] E. Ali, "Metode User Centered Design (Ucd) Dalam Membangun Aplikasi Layanan Manajerial Di Perguruan Tinggi," Satin-Sains Dan Teknologi Informasi, Vol. 2, No. 2, Pp. 1-6, 2016.

[14] I. A. Astuti, S. Suyanto, And S. Sukoco, "Penerapan Metode User Centered Design Pada Game Based Learning Terhadap Motivasi Belajar Siswa," Informasi Interaktif, Vol. 2, No. 1, Pp. 10-20, 2017.

[15] I. Afrianto and S. Sufaatin, "Rancang Bangun Model Agregator Jurnal Online," In Seminar Nasional Aplikasi Teknologi Informasi (Snati), Yogyakarta, 2017, Pp.D9-D16. 